[Article]

\title{
铜掺氧化锌多孔纳米棒的水热合成及其光催化性能
}

\author{
王元有 ${ }^{1,2}$ 周国强 ${ }^{1} \quad$ 张 龙 $^{1} \quad$ 刘天晴 $^{1, *}$ \\ ('扬州大学化学化工学院, 江苏省环境材料与环境工程重点实验室, 江苏扬州 225002; \\ 2扬州工业职业技术学院化工系, 江苏扬州 225127)
}

\begin{abstract}
摘要: 通过两步法合成铜掺杂的氧化锌纳米棒, 通过 X 射线衍射 (XRD)、扫描电子显微镜(FESEM)、透射电 子显微镜(TEM)、X射线光电子能谱(XPS)和紫外-可见(UV-Vis)分光光谱等技术对系列样品进行了表征, 研 究并探索了铜掺杂的氧化锌纳米棒光降解染料罗丹明 B (RhB) 和气体乙醛的催化活性。通过对多孔 Cu掺杂 $\mathrm{ZnO}$ 纳米棒光催化分解乙醛进行了评价。多孔 $\mathrm{Cu}$ 掺杂 $\mathrm{ZnO}$ 纳米棒 $(\mathrm{CZ}-5)$ 光催化剂具有最高的催化分解乙醛 的能力, 比其它多孔 $\mathrm{Cu}$ 掺杂 $\mathrm{ZnO}$ 纳米棒具有很高的催化活性。多孔 $\mathrm{Cu}$ 掺杂 $\mathrm{ZnO}$ 纳米棒光催化剂在室温下 在可见光 $(435 \mathrm{~nm})$ 下照射 $16 \mathrm{~h}, 5.50 \times 10^{-4}(\varphi$, 体积分数 $)$ 的乙醛气体完全降解为二氧化碳 $\left(\mathrm{CO}_{2}\right)$ 。多孔铜掺 杂的氧化锌纳米棒光催化剂的光催化性能的改善主要归因于铜和氧化锌纳米棒之间的协同作用。这种改进的 光催化协同作用归因于 $\mathrm{Cu}$ 掺杂 $\mathrm{ZnO}$ 的可见光吸收的延伸和光生电子空穴对的抗重组。
\end{abstract}

关键词: 半导体; 铜掺杂的氧化锌; 纳米棒; 光催化

中图分类号: 0643

\section{Synthesis and Photocatalytic Characterization of Porous Cu-Doped ZnO Nanorods}

\author{
WANG Yuan-You ${ }^{1,2} \quad$ ZHOU Guo-Qiang ${ }^{1} \quad$ ZHANG Long ${ }^{1} \quad$ LIU Tian-Qing, \\ ('Jiangsu Key Laboratory of Environmental Material and Environmental Engineering, School of Chemistry and \\ Chemical Engineering, Yangzhou University, Yangzhou 225002, Jiangsu Province, P. R. China; \\ ${ }^{2}$ Department of Chemical Engineering, Yangzhou Polytechnic Institute, Yangzhou 225127, Jiangsu Province, P. R. China)
}

\begin{abstract}
A two-step method was developed for the selective synthesis of porous $\mathrm{ZnO}$ nanorods (undoped and $\mathrm{Cu}$ doped): first, $\mathrm{Zn}\left[\mathrm{C}_{6} \mathrm{H}_{4}(\mathrm{COO})_{2}\right] \cdot \mathrm{H}_{2} \mathrm{O}$ and $\mathrm{Cu}$ doped $\mathrm{Zn}\left[\mathrm{C}_{6} \mathrm{H}_{4}(\mathrm{COO})_{2}\right] \cdot \mathrm{H}_{2} \mathrm{O}$ nanorods were synthesized via the hydrothermal reaction of $\mathrm{Zn}\left(\mathrm{NO}_{3}\right)_{2} \cdot 6 \mathrm{H}_{2} \mathrm{O}, \mathrm{NaOH}, \mathrm{KHC}_{8} \mathrm{H}_{4} \mathrm{O}_{4}$, and $\mathrm{Cu}\left(\mathrm{NO}_{3}\right)_{2} \cdot 3 \mathrm{H}_{2} \mathrm{O}$ at $120{ }^{\circ} \mathrm{C}$ for $6 \mathrm{~h}$; second, porous undoped and doped $\mathrm{ZnO}$ nanorods were obtained by thermal decomposition of the precursors in air at $500{ }^{\circ} \mathrm{C}$ for $2 \mathrm{~h}$, respectively. The porous $\mathrm{ZnO}$ nanorods were characterized by X-ray diffraction (XRD), scanning electron microscopy (SEM), transmission electron microscopy (TEM), X-ray photoelectron spectroscopy (XPS), and ultraviolet-visible (UV-Vis) spectroscopy. The photocatalytic degradation of rhodamine B (RhB) aqueous solution shows that the porous $\mathrm{Cu}$-doped $\mathrm{ZnO}$ nanorods have the highest photodegradation performance with visible light and acetaldehyde $\left(\mathrm{CH}_{3} \mathrm{CHO}\right)$ gas degradation. These results are because of the special interface structures of the catalysts and fast separation of its photogenerated charge carriers. These favorable photocatalytic properties of the doped microstructures demonstrate their potential for degradation of wastewater and aldehydes.
\end{abstract}

Received: June 27, 2016; Revised: August 30, 2016; Published online: August 30, 2016.

*Corresponding author. Email: tqliu@yzu.edu.cn; Tel: +86-514-87975244.

The project was supported by the National Natural Science Foundation of China (21505118), Natural Science Foundation of Jiangsu Province, China (BK2150438), Jiangsu Key Laboratory of Environmental Material and Environmental Engineering, China (K13065), Priority Academic Program Development of Jiangsu Higher Education Institutions, Senior Visiting Scholar Program of Jiangsu Higher Vocational College, China (2015FX089), and Qing Lan Project of Jiangsu Province, China.

国家自然科学基金(21505118), 江苏省自然科学基金(BK2150438), 江苏省环境材料与环境工程重点实验室开放课题(K13065), 高职院校高级 访问学者计划(2015FX089)和江苏省 “青蓝工程” 资助项目

(C) Editorial office of Acta Physico-Chimica Sinica 
Key Words: Semiconductor; Cu-doped ZnO; Nanorod; Photocatalysis

\section{Introduction}

Acetaldehyde $\left(\mathrm{CH}_{3} \mathrm{CHO}\right)$ is a major pollutant that causes sick house syndrome and is a common outdoor pollutant found in many industrial products, including paints, treated wood, solvents, plastics, and fabrics. The indoor environment plays an important role in human health, because people generally spend more than $80 \%$ of their time in indoors, which contributes a higher risk from inhalation of pollutants than outdoors. Furthermore, acetaldehyde is a colorless, flammable, widespread gas in air at room temperature. So people are mostly exposed to acetaldehyde by inhalation. Low-level exposure to acetaldehyde could cause damage to the human body, related symptoms such as eye and throat irritation, chest tightness and breath shortness. High-dose exposure increases the risk of acute poisoning, while prolonged exposure may lead to chronic toxicity and even cancer, Hence, it is necessary to identify and remove acetaldehyde from the indoor environment for improving indoor air quality and human being's health. In addition, because of the increasing concern on $\mathrm{CH}_{3} \mathrm{CHO}$ in the indoor environment, the abatement of $\mathrm{CH}_{3} \mathrm{CHO}$ is of significant practical interest at low temperature, especially at room temperature. Many studies have been carried out on the abatement and removal of acetaldehyde from the atmosphere, and a number of effective methods have been developed. Among several methods used in the removal of acetaldehyde in an indoor environment, the most economical and simple way is photocatalytic removal of the acetaldehyde for indoor air purification. This method has many advantages, such as high removal efficiency, a low function temperature (room temperature), atmospheric pressure, a wide range of applications, simple operation of equipment, and no secondary pollution. Thus, photocatalytic technology is drawing attention as a way to get rid of acetaldehyde. Photocatalytic approach commonly uses semiconductor photocatalytic material. In Previous studies, A lot of semiconductors have been applied in photocatalytic for formaldehyde degradation, such as $\mathrm{ZnO}, \mathrm{CeO}_{2}$, $\mathrm{Ta}_{2} \mathrm{O}_{5}, \mathrm{InVO}_{4}, \mathrm{MnO}_{2}, \mathrm{TiO}_{2}$, and $\mathrm{Bi}_{2} \mathrm{O}_{3}{ }^{1-9}$. Doping a single metal or nonmetal into ultraviolet light-active titanium dioxide photocatalysts have been the most attractive strategies to design and develop efficient visible light active $\mathrm{TiO}_{2}$ nanoparticle photocatalysts for decontamination of toxic organic compounds in polluted air and water, such as $(\mathrm{Sr}, \mathrm{N}) / \mathrm{TiO}_{2}{ }^{10},(\mathrm{Ni}, \mathrm{B}) / \mathrm{TiO}_{2}{ }^{11},(\mathrm{La}, \mathrm{N}) / \mathrm{TiO}_{2}{ }^{12}$, $(\mathrm{La}, \mathrm{S}) / \mathrm{TiO}_{2}{ }^{13},(\mathrm{Fe}, \mathrm{C}) / \mathrm{TiO}_{2}{ }^{14},(\mathrm{~V}, \mathrm{~B}) / \mathrm{TiO}_{2}{ }^{15}$, and $(\mathrm{V}, \mathrm{C}) / \mathrm{TiO}_{2}{ }^{16}$, have been developed and investigated especially for environmental remediation purposes. To the best of the authors' knowledge, there are no reports on acetaldehyde degradation with $\mathrm{Cu}-$ doped $\mathrm{ZnO}$ photocatalysts. photocatalytic degradation of organic pollutants has attracted great interest due to its unique features. Among various semiconductor materials, $\mathrm{ZnO}$ is one of the most promising candidates for the degradation of organic pollutants because of its low cost, environmental friendliness and wide band gap $(3.37 \mathrm{eV})$. Various $\mathrm{ZnO}$ nanostructures were prepared and utilized as efficient photocatalysts for the photocatalytic degra- dation of various organic pollutants ${ }^{17-22}$. However, poor photon absorption of $\mathrm{ZnO}$ limits its application in visible light photocatalyst due to a wide band gap of $3.37 \mathrm{eV}$. In order to shift the optical absorption of $\mathrm{ZnO}$ into the visible region, one possible approach is to dope $\mathrm{ZnO}$ photocatalyst with various impurities. $\mathrm{Cu}$ is the best choice as impurity for $\mathrm{ZnO}$ due to the minimum size mismatch between $\mathrm{Cu}$ and $\mathrm{Zn}$. A few methods have been used successfully to synthesize the $\mathrm{Cu}$-doped $\mathrm{ZnO}$ nanostructures ${ }^{23-27}$. In spite of achievements in the synthesis of $\mathrm{Cu}$-doped $\mathrm{ZnO}$ nanostructures, further exploration of some facile, mild, low-cost, and high-yield synthetic routes to manufacture tailored nanostructured materials is still desired. A study of a more complicated system will provide deeper insight into the development of a more practical catalyst applicable to a real contaminated target. The obtained $\mathrm{Cu}$-doped $\mathrm{ZnO}$ nanostructures show remarkably enhanced photocatalytic performances for acetaldehyde degradation under simulated solar light irradiation, higher than those of pure $\mathrm{ZnO}$ materials. Furthermore, the photocatalytic activity enhancement mechanism of the $\mathrm{Cu}$-doped $\mathrm{ZnO}$ nanostructures and the process of charge separation and transfer at the surface or interface were also discussed. Herein, we reported a simple and economical two step reactions to synthesize uniform $\mathrm{Cu}$-doped $\mathrm{ZnO}$ nanorods, which displayed high visible light photodegradation activities for the degradation of $\mathrm{RhB}$ aqueous solution and acetaldehyde $\left(\mathrm{CH}_{3} \mathrm{CHO}\right)$ gas.

\section{Experimental}

\subsection{Materials}

All the chemical reagents used in this work include sodium hydroxide $(\mathrm{NaOH}), \mathrm{H}_{2} \mathrm{O}_{2}(30 \%$ ( $w$, mass fraction)), zinc nitrate hexahydrate $\left(\mathrm{Zn}\left(\mathrm{NO}_{3}\right)_{2} \cdot 6 \mathrm{H}_{2} \mathrm{O}\right)$, copper nitrate trihydrate $\left(\mathrm{Cu}\left(\mathrm{NO}_{3}\right)_{2} \cdot 3 \mathrm{H}_{2} \mathrm{O}\right)$, potassium hydrogen phthalate $\left(\mathrm{KHC}_{8} \mathrm{H}_{4} \mathrm{O}_{4}\right)$, rhodamine $\mathrm{B}(\mathrm{RhB})$, acetaldehyde $\left(\mathrm{CH}_{3} \mathrm{CHO}\right)$, and ethanol $\left(\mathrm{C}_{2} \mathrm{H}_{5} \mathrm{OH}\right)$. All chemicals were analytically pure and were used as received without further purification. Deionized water was used throughout the experiment. All reagents were from Shanghai Chemicals Inc., China. All reagents were analytically pure.

\subsection{Methods}

A typical synthesis of precursor (zinc phthalate hydrate) is as follows: $6 \mathrm{mmol} \mathrm{Zn}\left(\mathrm{NO}_{3}\right)_{2} \cdot 6 \mathrm{H}_{2} \mathrm{O}$ was dissolved in $50 \mathrm{~mL}$ distilled water and then $6 \mathrm{mmol} \mathrm{KHC}_{8} \mathrm{H}_{4} \mathrm{O}_{4}$ was put into the solution with stirring. After that, $12 \mathrm{mmol} \mathrm{NaOH}$ was added into the above solution. Finally the mixed solution was transferred into a Teflonlined autoclave of $80 \mathrm{~mL}$ capacity and was filled up to $85 \%$ of the total volume with deionized water. After being sealed and heated at $120^{\circ} \mathrm{C}$ for $6 \mathrm{~h}$, the autoclave was cooled to room temperature naturally. The resulting products were collected by centrifugation, washed with distilled water and ethanol for several times, and finally dried in vacuum at $70{ }^{\circ} \mathrm{C}$ for $6 \mathrm{~h}$. To obtain $\mathrm{Cu}$ doped precursor, similar procedure was performed under the same reaction condition except using $6 \mathrm{mmol} \mathrm{Zn}\left(\mathrm{NO}_{3}\right)_{2} \cdot 6 \mathrm{H}_{2} \mathrm{O}$ and dif- 
ferent stoichiometric amounts of $\mathrm{Cu}\left(\mathrm{NO}_{3}\right)_{2} \cdot 3 \mathrm{H}_{2} \mathrm{O}$ were added to the resultant mixed solution. Porous $\mathrm{Cu}$-doped $\mathrm{ZnO}$ nanorods could be yielded when the precursors were heated in a muffle oven at $500{ }^{\circ} \mathrm{C}$ for $2 \mathrm{~h}$, respectively. $\mathrm{Cu}$-doped $\mathrm{ZnO}$ nanorods were prepared for different $\mathrm{Cu}^{2+}$ molar concentrations namely $1 \%, 2 \%$, and $5 \%$, and were indexed as samples ' $\mathrm{CZ}-1$ ', ' $\mathrm{CZ}-2$ ', and ' $\mathrm{CZ}-$ 5 ', respectively.

\subsection{Characterization}

The phase purity of the products was characterized by X-ray diffraction (XRD, German Bruker AXSD8 ADVANCE X-ray diffractometer) using a X-raydiffractometer with $\mathrm{Cu} K_{a}$ radiation $(\lambda=0.15418 \mathrm{~nm})$. Morphology information of theas-prepared particles was obtained on a Japan Hitachi S-4800 field emission scanningelectron microscope (SEM). Transmission electron microscope (TEM) images, highresolution transmission electron microscopy (HRTEM) images, high angle annulardark field (HAADF) images, and elemental mapping images were obtained on an American FEI Tecnai G2 F30 S-TWIN field-emission transmission electronmicroscopy (operated at $300 \mathrm{kV}$ ). Diffuse reflectance spectra (DRS) were measured using a UV-Vis spectrophotometer (Shimadzu, UV-2600) equipped with an integrating sphere unit (Shimadzu, ISR-2600 Plus). Fluorescence spectra were obtained using a photoluminescence spectrometer (JASCO, FP8500). X-ray photoelectron spectra (XPS) were recorded on an ESCALAB 250Xi system (Thermo Scientific).

\subsection{Photocatalytic testing}

$\mathrm{RhB}$ aqueous solution photodegradation evaluation test: the photocatalytic activities of as-prepared products were tested by degrading an organic dye, $\mathrm{RhB}$ in aqueous solution. A mixture of $60 \mathrm{~mL} 1 \times 10^{-5} \mathrm{~mol} \cdot \mathrm{L}^{-1} \mathrm{RhB}$ aqueous solution, $5 \mathrm{~mL} \mathrm{H}_{2} \mathrm{O}_{2}(30 \%$ $(w))$, and $10 \mathrm{mg}$ prepared samples were put in bottle with a capacity of $200 \mathrm{~mL}$ and stirred in the dark for $30 \mathrm{~min}$. Then the mixture was continuously agitated throughout the experiment and irradiated by a $250 \mathrm{~W}$ Xe lamp, cut-off filter $(>420 \mathrm{~nm})$. After a given irradiation time, about $3 \mathrm{~mL}$ the mixture was withdrawn and immediately centrifuged. The photocatalytic degradation process of $\mathrm{RhB}$ was monitored by measuring its absorption with a UV-Vis spectrophotometer.

$\mathrm{CH}_{3} \mathrm{CHO}$ gaseous phase photo degradation evaluation test: 0.1 $\mathrm{g}$ samples were spread on the bottom of a watch-glass. The watch- glass was put and $125 \mathrm{~mL} 5.50 \times 10^{-4}(\varphi$, volume fraction $)$ acetaldehyde/pure air mixture gases were injected into the Tedlar bag (polyvinyl fluoride, As ONE Co. Ltd.). The bag was located in dark room for $2 \mathrm{~h}$ to ensure the adsorption equilibrium. Then the samples were irradiated under LED lamp (central wavelength of $435 \mathrm{~nm}$ ) with $3 \mathrm{~mW} \cdot \mathrm{cm}^{-2}$ light intensity. The concentration variation of acetaldehyde and $\mathrm{CO}_{2}$ evolution were monitored by on-line gas chromatography (Agilent Technologies, 3000A MicroGC, TCD detector) equipped with OV1 and PLOT-Q columns.

\section{Results and discussion}

\subsection{XRD curves of as-synthesized samples}

The crystal structures of the as-prepared precursor and the samples obtained after annealing were characterized via XRD (Fig.1). In Fig.1(a), it can be seen that all peaks of the precursor can be indexed to zinc phthalate hydrate $\mathrm{Zn}\left[\mathrm{C}_{6} \mathrm{H}_{4}(\mathrm{COO})_{2}\right] \cdot \mathrm{H}_{2} \mathrm{O}$. $\mathrm{ZnO}$ and $\mathrm{Cu}$-doped $\mathrm{ZnO}$ nanorods were obtained after calcination of the precursor in air at $500{ }^{\circ} \mathrm{C}$ (Fig.1(b)). It was found that all the samples exhibited the typical character of wurtzite hexagonal phase structure according to the standard JCPDS (36-1451) card. No any other impure diffraction peaks were detected, At low $\mathrm{Cu}^{2+}$ concentration the local supersaturation is not achieved and hence $\mathrm{Cu}^{2+}$ ions may be incorporated into $\mathrm{ZnO}$ lattice suggesting that $\mathrm{Cu}$ is highly dispersed in the sample, or they are too small to be detected. With further increase in the $\mathrm{Cu}^{2+}$ concentration, new peak appearing at $2 \theta=38.6^{\circ}$ was found when the molar content of $\mathrm{Cu}$ atoms was increased to $5 \%$ ( $x$, molar fraction), which are attributed to (111) plane for the $\mathrm{CuO}$ crystalline structure.

\subsection{Component analysis and Barrett-Emmett-Teller tests of $\mathrm{ZnO}$ samples}

To understand the component of these pure $\mathrm{ZnO}$ and $\mathrm{Cu}$-doped $\mathrm{ZnO}$ samples clearly, the total amount of $\mathrm{Cu}$ in $\mathrm{ZnO}$ was determined by WDXRF and the results are shown in Table 1. It shows that each of the samples has similar composition and if contains $\mathrm{Zn}$ and $\mathrm{Cu}$. Thus, it can be concluded that the as-synthesized samples are devoid of any other impurity atoms. It can also be found that the atomic ratio of $\mathrm{Cu} / \mathrm{Zn}$ was to be about $0.000,0.009$, $0.025,0.046$, which is close to the experimental dopant concentration.

Furthermore, the obvious changes can be seen in Barrett-
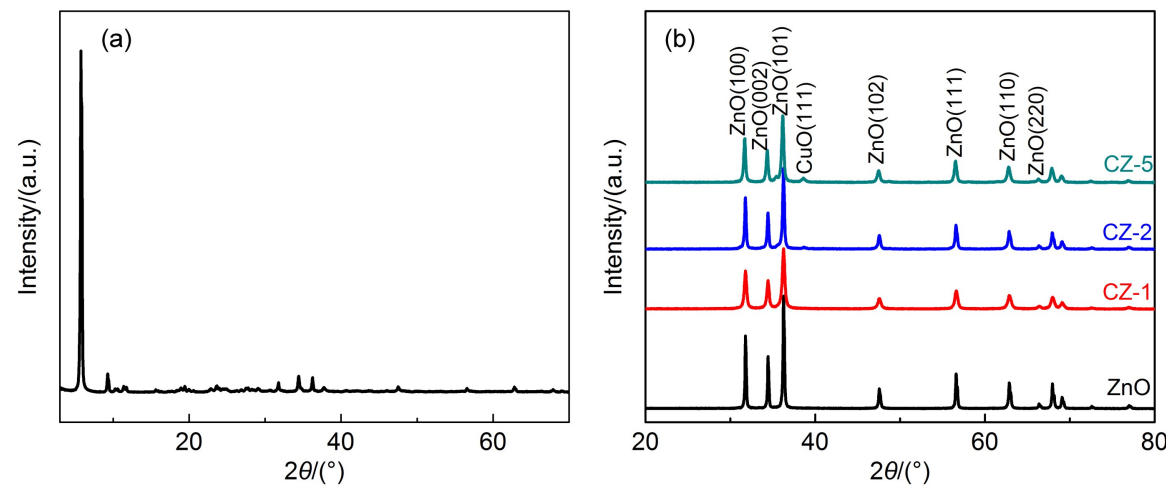

Fig.1 XRD patterns of (a) $\mathrm{Zn}\left[\mathrm{C}_{6} \mathrm{H}_{4}(\mathrm{COO})_{2}\right] \cdot \mathrm{H}_{2} \mathrm{O}$ precursors, (b) $\mathrm{ZnO}$ and $\mathrm{Cu}$-doped $\mathrm{ZnO}$ nanorods 
Table 1 Elemental composition, pore size and BET of the as-synthesized samples

\begin{tabular}{cccc}
\hline Sample & Atomic ratio of $\mathrm{Cu} / \mathrm{Zn}$ & $S_{\mathrm{BET}} /\left(\mathrm{m}^{2} \cdot \mathrm{g}^{-1}\right)$ & Pore size $/ \mathrm{nm}$ \\
\hline pure $\mathrm{ZnO}$ & 0.000 & 4.89 & 8.31 \\
$1 \%(x) \mathrm{Cu}$-doped $\mathrm{ZnO}$ & 0.009 & 6.92 & 7.96 \\
$2 \%(x) \mathrm{Cu}$-doped $\mathrm{ZnO}$ & 0.025 & 12.24 & 5.95 \\
$5 \%(x) \mathrm{Cu}$-doped $\mathrm{ZnO}$ & 0.046 & 12.49 & 5.98 \\
\hline
\end{tabular}

Emmett-Teller (BET) and pore size of the as-synthesized pure $\mathrm{ZnO}$ and $\mathrm{Cu}$-doped $\mathrm{ZnO}$, which are shown in Table 1. Comparing with the specific surface area pore size of pure $\mathrm{ZnO}$, the specific surface area of $\mathrm{Cu}$-doped $\mathrm{ZnO}$ samples have been enlarged, which may be suitable for increasing the photocatalytic activity of the $\mathrm{Cu}$ doped $\mathrm{ZnO}$ samples.

\subsection{FESEM and HRTEM images of the samples}

The morphologies of the precursor and $\mathrm{ZnO}$ were investigated with SEM. Fig.2(a) shows the SEM images of the precursor. It can be seen that $\mathrm{Zn}\left[\mathrm{C}_{6} \mathrm{H}_{4}(\mathrm{COO})_{2}\right] \cdot \mathrm{H}_{2} \mathrm{O}$ precursor much was obtained. The length of a single nanorod was approximately $3-5 \mathrm{~mm}$ and the diameter varied in the range between $70-150 \mathrm{~nm}$. Compared with the precursor, the composition analyses of the $5 \%(x) \mathrm{Cu}-$ doped $\mathrm{ZnO}$ sample were characterized by HRTEM energy-dispersive X-ray spectroscopy (EDS) mapping (scanning model of HRTEM) using a FEI F30 microscope equipped with an EDAX energy EDS. High resolution scanning transmission electron microscopy-EDS (HRSTEM-EDS) mapping results in Fig.2(i-1) of as-synthesized 5\% $(x) \mathrm{Cu}$-doped $\mathrm{ZnO}$ sample revealed that the composition of the sample contains $\mathrm{Cu}, \mathrm{Zn}$ and $\mathrm{O}$. Thus, it can be
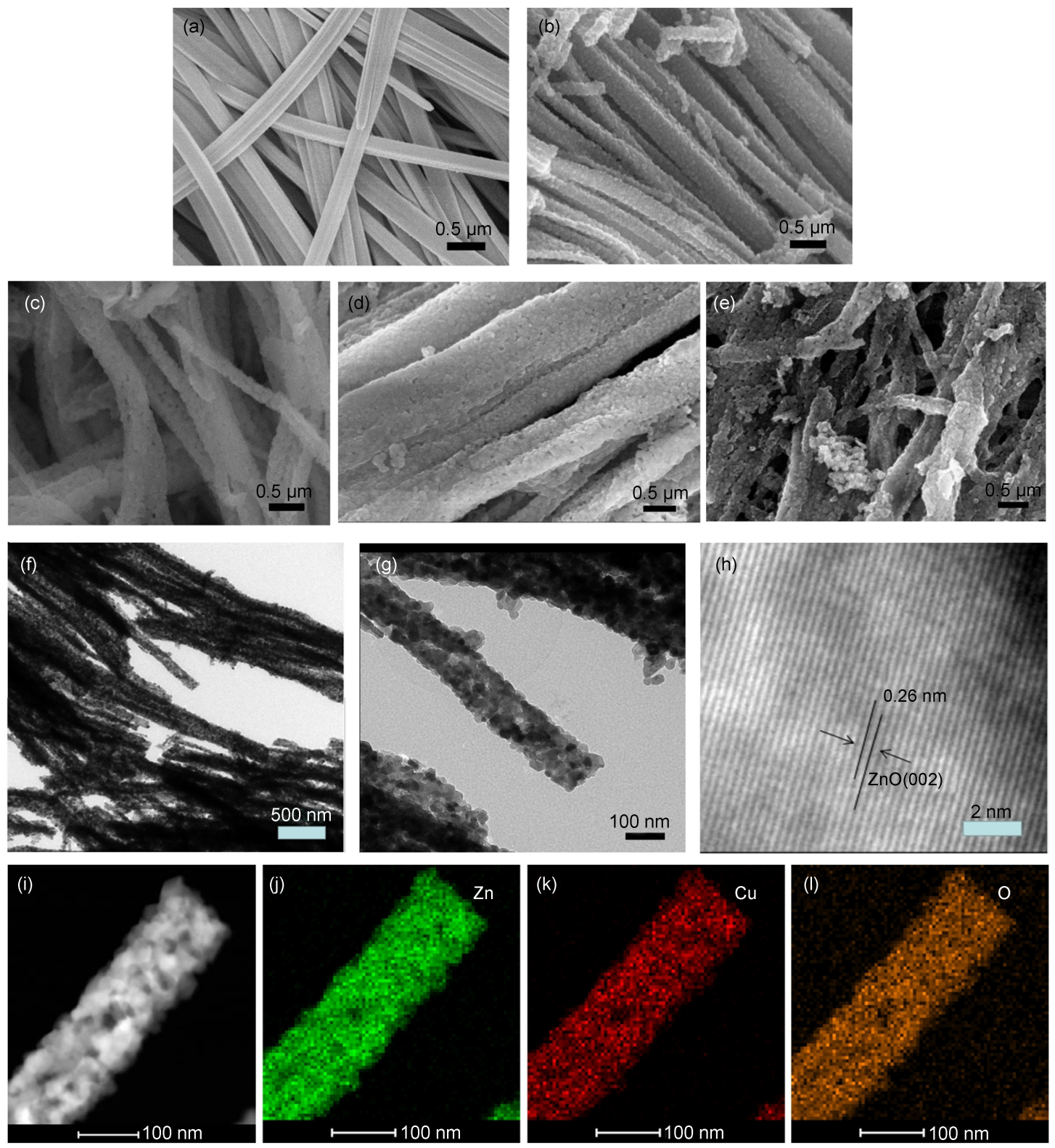

Fig.2 FESEM images of (a) $\mathrm{Zn}\left[\mathrm{C}_{6} \mathrm{H}_{4}(\mathrm{COO})_{2}\right] \cdot \mathrm{H}_{2} \mathrm{O}$ precursor, (b) $\mathrm{ZnO}$ nanorods, and (c-e) $\mathrm{Cu}$-doped $\mathrm{ZnO}$ nanorods $(\mathrm{CZ}-1, \mathrm{CZ}-2$, and $\mathrm{CZ}-5$ ); (f, g) TEM images of $\mathrm{Cu}$-doped $\mathrm{ZnO}$ nanorods; (h) HRTEM image of $\mathrm{Cu}$-doped $\mathrm{ZnO}$ nanorods; (i-l) STEM image and elemental mapping of a single $\mathrm{Cu}$-doped $\mathrm{ZnO}$ nanorod 
concluded that the as-synthesized 5\% (x) Cu-doped $\mathrm{ZnO}$ sample were devoid of any other impurity. As-prepared samples (undoped $\mathrm{ZnO}$ and $\mathrm{Cu}$-doped $\mathrm{ZnO}$ ) after calcination in air possessed similar rod shape morphology (Fig.2(b) and Fig.2(c-e)). However, the surface of rods has become much rough. For Cu-doped $\mathrm{ZnO}$ (CZ5 ), it looked like bead-like chains composed of lots of nanoparticles bound with each other along a definite direction from the TEM image (Fig.2(f)). And a lot of pores were found in the enlarge TEM image (Fig.2(g)). The porous structure on the $\mathrm{ZnO}$ nanorods would be the result of loss of volatile gases such as $\mathrm{H}_{2} \mathrm{O}$ and $\mathrm{CO}_{2}$ during the heat treatment. The interplanar spacing of 0.26 $\mathrm{nm}$ in Fig.2(h) is equal to the bulk $\mathrm{ZnO}$ (002), indicating that the crystal lattice does not expand or contract. The STEM and elemental mapping images (Fig.2(i-1)) further confirm that the $\mathrm{Cu}$ doped $\mathrm{ZnO}$ nanorods were prepared. Different colors indicate different elements: green, red, and orange refer to $\mathrm{Zn}, \mathrm{Cu}$, and $\mathrm{O}$ elements, respectively.

\subsection{UV-Vis diffuse reflectance spectra}

The optical absorption spectra of undoped and $\mathrm{Zn}_{1-x} \mathrm{Cu}_{x} \mathrm{O}$ (where $x=0.0,0.010,0.02,0.05)$ samples by UV-DRS spectrum in the range of 200-800 nm were presented. From Fig.3(a), it can be seen that the excitonic absorption peak of undoped $\mathrm{ZnO}$ and $\mathrm{Cu}-$ doped $\mathrm{ZnO}$ nanorods appear around $375 \mathrm{~nm}$, which is the absorption edge of $\mathrm{ZnO}$. The excitonic absorption peak of as prepared undoped and $\mathrm{Cu}$ doped samples become broad as the molar ratio increases. In addition, for $\mathrm{Cu}$-doped $\mathrm{ZnO}$ nanorods, a broad absorption covers the range of $400-800 \mathrm{~nm}$. This may be attributed to efficient harvesting of visible light by $\mathrm{Cu}$-doping in $\mathrm{ZnO}$ and provides the possibility of enhancing visible light absorption $^{28}$. Fig.3(b) shows the representative photoluminescence (PL) spectra of the as-prepared samples with the excitation wavelength of $325 \mathrm{~nm}$ at room temperature. There are two peaks in undoped $\mathrm{ZnO}$ : one is the UV near-band-edge (NBE) emission centered at $375 \mathrm{~nm}$; the other is a broad green region centered at $580 \mathrm{~nm}$. Compared with that of pure $\mathrm{ZnO}$, the emission of $\mathrm{Cu}-$ doped $\mathrm{ZnO}$ is dramatically reduced, It might also suggest that the green emission of the as-synthesized Cu-doped $\mathrm{ZnO}$ (CZ-5) samples may be attributed to oxygen vacancies defects at the surface or in the bulk. indicating the decreased recombination of photogenerated holes with the electrons in intrinsic or extrinsic defects after photo irradiation process, which will enhance the photocatalytic efficiency. Fig.3(c) shows a plot of $(\alpha h v)^{2} v s h v$, which gives an absorption edge energy that corresponds to the band gap $\left(E_{\mathrm{g}}\right)$. The band gaps of the $\mathrm{Cu}$-doped $\mathrm{ZnO}$ products were estimated to be $3.16,3.01,2.97$, and $2.92 \mathrm{eV}$, respectively. The effect of $\mathrm{Cu}-$ doped $\mathrm{ZnO}$ products is clearly noted on its band gap.

\subsection{XPS spectra of the samples}

To clarify the elemental composition and chemical state of the as-synthesized 5\% $(x) \mathrm{Cu}$-doped $\mathrm{ZnO}$ nanorods, XPS spectra were carried out with the binding energies calibrated using C $1 s$ (284.8 $\mathrm{eV}$ ), as shown in Fig.4. The peaks can be ascribed to $\mathrm{Zn}, \mathrm{O}, \mathrm{C}$, and $\mathrm{Cu}$ (Fig.4(a)) confirming the sample is prepared comparing to the only $\mathrm{Zn}, \mathrm{O}, \mathrm{C}$ elements present in the $5 \%(x) \mathrm{Cu}$-doped $\mathrm{ZnO}$
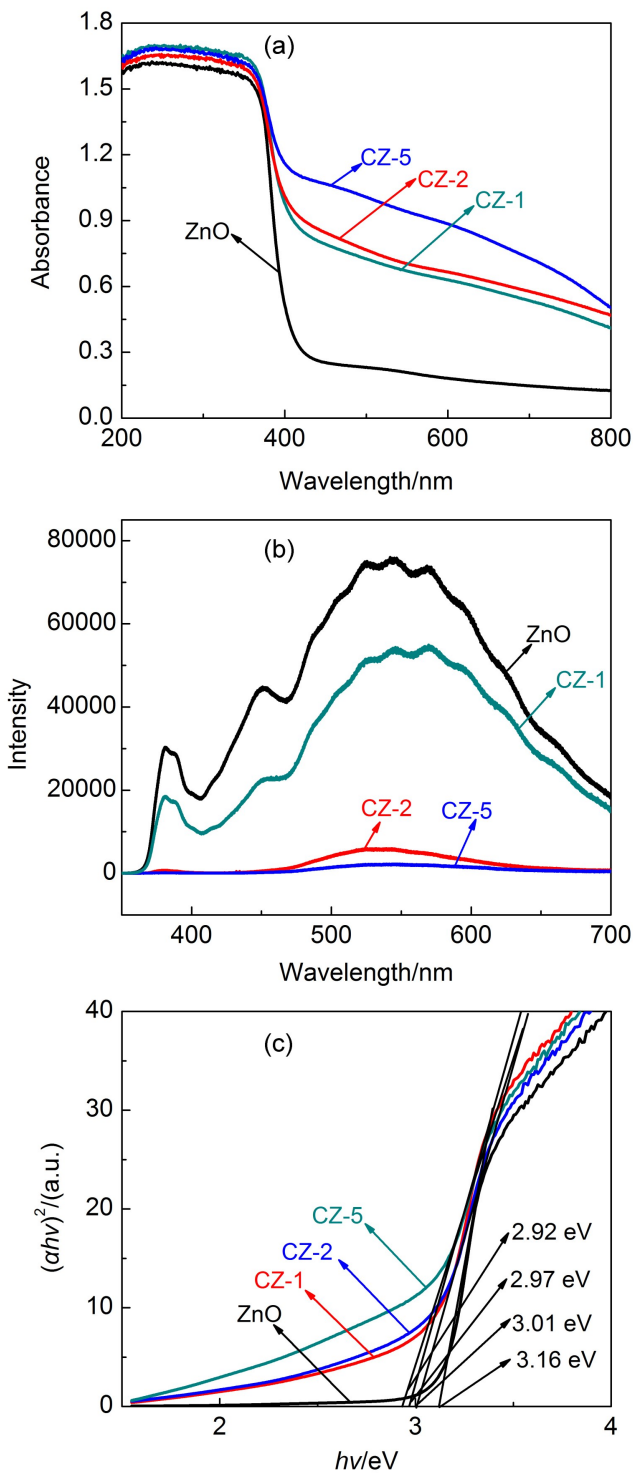

Fig.3 (a) DRS and (b) PL spectra of $\mathrm{ZnO}$ and

$\mathrm{Cu}$ doped $\mathrm{ZnO}$ nanorods and (c) plots of $(\alpha h v)^{2} v s h$ for $\mathrm{ZnO}, \mathrm{CZ}-1, \mathrm{CZ}-2$, and $\mathrm{CZ}-5$

nanorods (Fig.4(b)) as shown in Fig.4. Zn, O, Cu elements were found in Fig.4. Two strong peaks in Fig.4 center on 1020.9 and $1043.9 \mathrm{eV}$, which are in agreement with the binding energies of $\mathrm{Zn}$ $2 p_{3 / 2}$ and $\mathrm{Zn} 2 p_{1 / 2}$, respectively. The $\mathrm{Cu} 2 p$ binding energies of the as-prepared samples were $932.6 \mathrm{eV}\left(\mathrm{Cu} 2 p_{3 / 2}\right)$ and $952.2 \mathrm{eV}(\mathrm{Cu}$ $2 p_{1 / 2}$ ), respectively, which also proved the existence of $\mathrm{Cu}^{2+}$ in the as-synthesized $\mathrm{Cu}$-doped $\mathrm{ZnO}$ sample. $\mathrm{O} 1 s$ profile is asymmetric and can be fitted into two symmetrical peaks at 529.9 and 531.3 $\mathrm{eV}$, which agrees well with the branched $\mathrm{ZnO}$ and the reported value for $\mathrm{ZnO}^{29,30}$. Therefore, the result of XPS further confirms that the samples are composed of $\mathrm{ZnO}$ and $\mathrm{CuO}$.

\subsection{Photocatalytic performance}

Photocurrents for the as-synthesized $\mathrm{Cu}-\mathrm{ZnO}$ and $\mathrm{ZnO}$ electrodes were also measured on a Zahner workstation (Zahner, German) with a LW405 light $\left(10 \mathrm{~mW} \cdot \mathrm{cm}^{-2}\right)$ as the accessory light source to investigate the electronic interaction between $\mathrm{CuO}$ and 

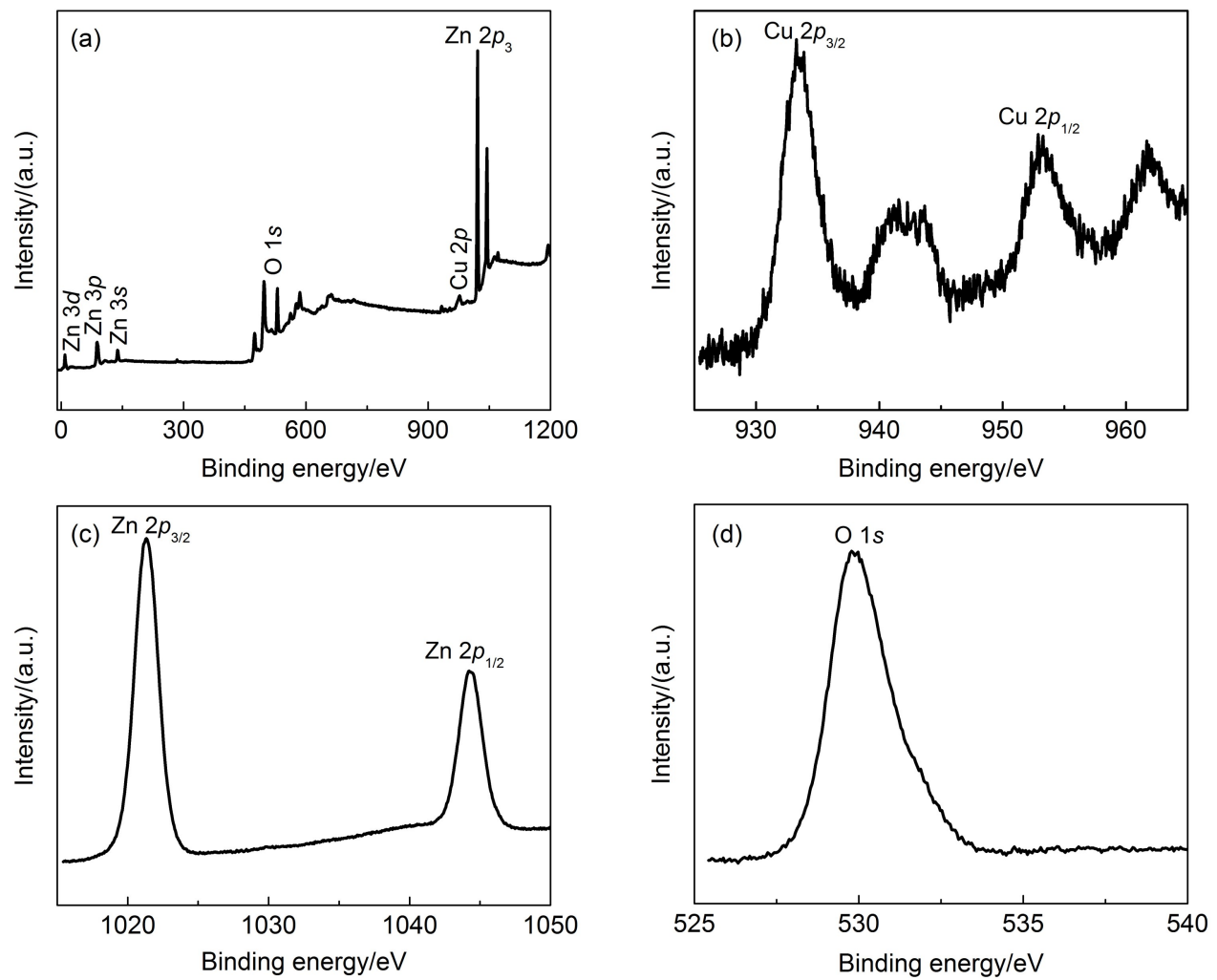

Fig.4 XPS spectra of the CZ-5 (a) and the scan of (b) Cu 2p, (c) Zn 2p, and (d) $\mathrm{O} 1 s$

$\mathrm{ZnO}$ (Fig.5). Generally, semiconductor photo catalysis involves the generation of electrons in the conduction band and holes in the valence band within a semiconductor upon light irradiation at energies equal to or greater than the band gap of the semiconductor. Subsequently, the utilization of photo excited charge carriers to initiate redox reactions with suitable substrates on the semiconductor surface. To further understand the heterojunction effect on the photocatalytic activity enhancement of CZ-5 nanorods,we carefully studied the photo induced charge transfer properties of the CZ-5 nanorods. It was clear that fast and uniform photocurrent responses were observed in both electrodes and the photoresponsive phenomenon was entirely reversible. Under visible light irradiation, It is known that the higher the photo-

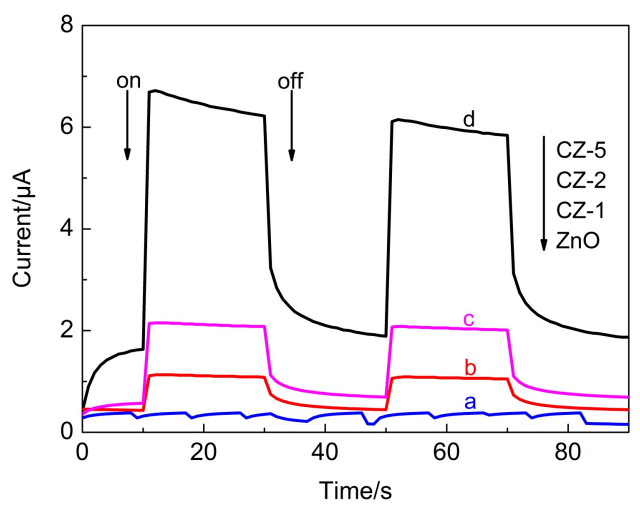

Fig.5 Transient photocurrent response for $\mathrm{ZnO}$ and $\mathrm{Cu}$ doped $\mathrm{ZnO}$ nanorods under visible light irradiation (a) $\mathrm{ZnO}$; (b) $\mathrm{CZ}-1$; (c) $\mathrm{CZ}-2$; (d) $\mathrm{CZ}-5$ current intensity, the more effective the separation of photo-induced carriers. The photocurrent density of the $\mathrm{Cu}-\mathrm{ZnO}$ electrode was higher than that of the pure $\mathrm{ZnO}$ electrode (Fig.5). The photocurrent enhancement of the $\mathrm{Cu}-\mathrm{ZnO}$ photocatalyst indicated an enhanced photoinduced electrons and holes separation when comparing with pure $\mathrm{ZnO}$.

The photocatalytic activities of as-fabricated products were evaluated by measuring $\mathrm{CO}_{2}$ evolution form the photocatalytic decomposition of acetaldehyde. Fig.6(a, b) shows the time course of $\mathrm{CO}_{2}$ liberation of samples with different of dopant concentrations. From Fig.6(a, b) we can conclude that the porous $\mathrm{Cu}$-doped $\mathrm{ZnO}$ nanorods (CZ-5) photocatalyst shows the highest $\mathrm{CO}_{2}$ generation concentration, which is higher activity than that of porous $\mathrm{ZnO}$ nanorods. When the dopant concentration is low $(<0.01 \mathrm{~mol})$, the as-fabricated samples show a low $\mathrm{CO}_{2}$ liberation rate as in the case of pure $\mathrm{ZnO}$. However, with increase in the concentration of the dopant, the $\mathrm{CO}_{2}$ liberation rate rapidly improved, which demonstrated that a high content dopant is beneficial for enhancement of photocatalytic activities. When the content of dopant reached $0.05 \mathrm{~mol}$, the fabricated sample showed the highest $\mathrm{CO}_{2}$ liberation rate, and with further increase in concentration of the dopant, the $\mathrm{CO}_{2}$ liberation rate decreased. Namely, $5.50 \times 10^{-4}(\varphi) \mathrm{CH}_{3} \mathrm{CHO}$ gas is fully degraded to $\mathrm{CO}_{2}$ by this porous $\mathrm{Cu}$-doped $\mathrm{ZnO}$ nanorods photocatalyst within $16 \mathrm{~h}$ at room temperature under $435 \mathrm{~nm}$ visible light irradiation. The photocatalytic performance improvement of the porous $\mathrm{Cu}$-doped $\mathrm{ZnO}$ nanorods photocatalyst is mainly attributed its intimate interfacial contact between $\mathrm{Cu}$ and $\mathrm{ZnO}$ nanorods. This improved 

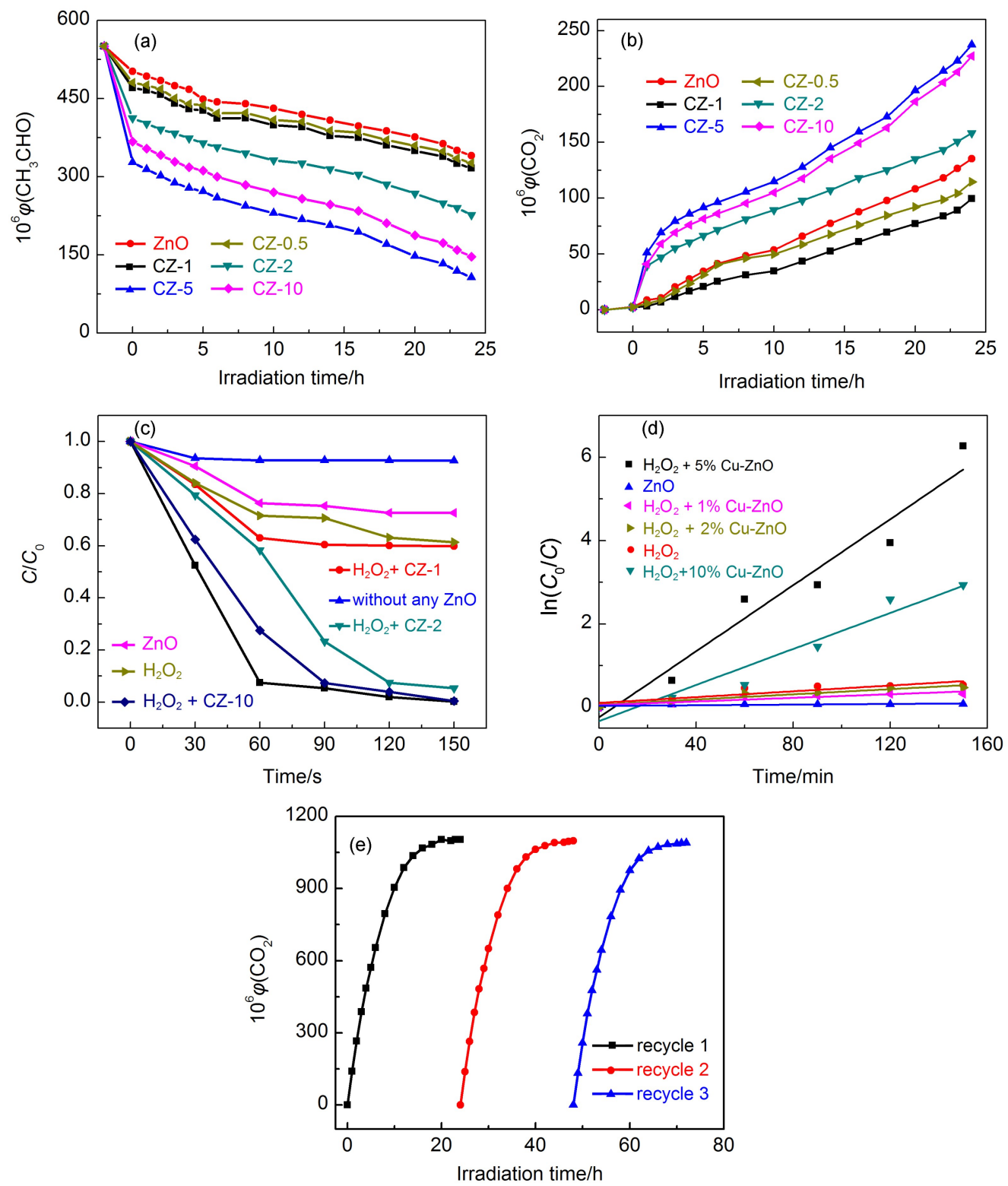

Fig.6 Photocatalytic performance evaluation curves of the as-prepared photocatalysts

(a) $\mathrm{CH}_{3} \mathrm{CHO}$ concentration; (b) $\mathrm{CO}_{2}$ generation; (c, d) RhB degradation; (e) three recycles of $\mathrm{CH}_{3} \mathrm{CHO}$

photocatalysis was attributed to the synergistic actions of $\mathrm{Cu}-$ doped $\mathrm{ZnO}$ for the extension of visible light absorption and the anti-recombination of photogenerated electron-hole pairs, which are also well accordance with the PL analysis results in Fig.3(b). Therefore, many more photogenerated holes and electrons prefer to be involved in the photocatalytic reaction rather than be annihilated by the form of radiation. Meanwhile, porous $\mathrm{Cu}$-doped $\mathrm{ZnO}$ nanorod is with good stability and high efficiency after photocatalytic reaction because this photocatalyst still retains $99 \%$ photocatalytic activity after three $\mathrm{CH}_{3} \mathrm{CHO}$ degradation recycles (Fig.6(e)). Besides, the photodegradation experiments of RhB aqueous solution were further carried out to investigate the universality of this photocatalyst. Obviously, RhB dyes photodegradation results in solution in Fig.6(c) present a similar tendency with $\mathrm{CH}_{3} \mathrm{CHO}$ ones in gaseous phase. In summary, porous $\mathrm{Cu}-$ doped $\mathrm{ZnO}$ nanorod has excellent photodegradation performance in $\mathrm{RhB}$ dye and $\mathrm{CH}_{3} \mathrm{CHO}$ gas under visible light irradiation. It is clear that optimal $\mathrm{Cu}$ doping has increased the photocatalytic degradation efficiency in comparison to undoped $\mathrm{ZnO}$ sample. Without any photocatalyst, the degradation of $\mathrm{RhB}$ hardly occurs when subjected to the visible light irradiation for $120 \mathrm{~min}$.

It is well known that the photocatalytic decomposition of organic pollutants accords with the pseudo first-order kinetic model. The degradation rate constant was calculated from the experimental data using Eq.(1) ${ }^{31}$,

$$
\ln \left(C_{0} / C\right)=k_{\mathrm{r}} t
$$

where, $k_{\mathrm{r}}$ is the degradation rate constant, and $t$ is the degradation time. The value of degradation rate constant $k_{\mathrm{r}}$ for $\mathrm{RhB}$ dyes was calculated from the slope of the kinetics plot obtained by plotting the natural logarithm of concentration ratio, $\ln \left(C_{0} / C\right)$, vs the ir- 
Table 2 Degradation parameter of $\mathrm{RhB}$ by the photocatalysts

\begin{tabular}{ccc}
\hline Sample & $k_{\mathrm{r}} / \mathrm{min}^{-1}$ & $r^{2}$ \\
\hline pure $\mathrm{ZnO}$ & $3.88 \times 10^{-4}$ & 0.95 \\
$1 \%(x) \mathrm{Cu}$-doped $\mathrm{ZnO}$ & 0.00217 & 0.93 \\
$2 \%(x) \mathrm{Cu}$-doped $\mathrm{ZnO}$ & 0.00312 & 0.94 \\
$5 \%(x) \mathrm{Cu}$-doped $\mathrm{ZnO}$ & 0.03961 & 0.95 \\
$10 \%(x) \mathrm{Cu}$-doped $\mathrm{ZnO}$ & 0.02161 & 0.96 \\
\hline
\end{tabular}

radiation time, $t$, as shown in Fig.6(d), respectively. The kinetic parameters like degradation rate constant $k_{\mathrm{r}}$, half-life value $\left(t_{1 / 2}\right)$, and linear coefficient $\left(r^{2}\right)$ calculated from the kinetics plots are given in Table 2.

The rate constant for the $5 \%(x) \mathrm{Cu}$-doped $\mathrm{ZnO}$ sample was $k=$ $3.9 \times 10^{-2} \mathrm{~min}^{-1}$. which was larger than that of the reported $\mathrm{Cu}-$ doped samples $\left(k=3.229 \times 10^{-2} \mathrm{~min}^{-1}\right)^{32}$ and that of the pure $\mathrm{ZnO}$ samples. These results reveal that $\mathrm{Cu}$ doping enhances the photocatalytic efficiency of pure $\mathrm{ZnO}$ under visible light.

Both $\mathrm{H}_{2} \mathrm{O}_{2}$ and $\mathrm{Cu}$-doped $\mathrm{ZnO}$ nanorods play an important role in the degradation of $\mathrm{RhB}$. Studies on oxidative degradation of organic dyes with $\mathrm{H}_{2} \mathrm{O}_{2}$ have been reported previously using $\mathrm{CuO}$ as catalys $\mathrm{t}^{33}$. The degradation proceeds by an adsorption-oxidationdesorption mechanism ${ }^{34,35}$. Several free radical species are believed to be responsible for the degradation of dyes, including $\mathrm{HO}$, $\mathrm{HOO} \cdot$, or $\mathrm{O}_{2}$.

In the current work, similar processes may also be involved. Firstly, $\mathrm{RhB}$ and $\mathrm{H}_{2} \mathrm{O}_{2}$ are adsorbed on the surface of $\mathrm{Cu}$-doped $\mathrm{ZnO}$ nanorods. Secondly, $\mathrm{H}_{2} \mathrm{O}_{2}$ is decomposed into free radical species, such as $\mathrm{HO}^{\cdot}, \mathrm{HOO}^{\cdot}$, or $\mathrm{O}_{2}^{*}$ as induced by the highly active catalyst. The nascent free radical species have high oxidative ability and cause destructive oxidation of the organic dye. Thirdly, small molecules from the dye degradation are desorbed of $\mathrm{Cu}$-doped $\mathrm{ZnO}$ nanorods surface, and the catalyst is recovered ${ }^{36}$.

Moreover, it can also be seen in BET, UV-Vis spectra and potocurrent spectra of the as-synthesized $\mathrm{ZnO}$ samples that the enhanced photocatalytic activity of $\mathrm{Cu}$-doped $\mathrm{ZnO}$ nanorods can also be attributed to enlarged surface area, higher excitonic peaks and enhanced photoinduced electrons and holes separation of the $\mathrm{Cu}$-doped $\mathrm{ZnO}$ sample.

The possible schematic diagram for $\mathrm{Cu}$-doped $\mathrm{ZnO}$ photocatalytic degradation of $\mathrm{RhB}$ dye and $\mathrm{CH}_{3} \mathrm{CHO}$ gas under visible light irradiation is shown in Scheme 1.

The proposed mechanism for the photocatalytic decomposition of organic pollutants by $\mathrm{Cu}$-doped $\mathrm{ZnO}$ nanorods can be described as follows:

$$
\begin{aligned}
& \mathrm{ZnO}+h v \rightarrow \mathrm{e}^{-}+\mathrm{h}^{+} \\
& \mathrm{e}^{-}+\mathrm{O}_{2} \rightarrow \cdot \mathrm{O}_{2}^{-} \\
& \mathrm{Zn}_{\mathrm{i}} / \mathrm{Cu}_{\mathrm{i}}+\mathrm{h}^{+} \rightarrow \mathrm{Zn}_{\mathrm{i}}^{+} / \mathrm{Cu}_{\mathrm{i}}^{+} \\
& \mathrm{Zn}_{\mathrm{i}}^{+} / \mathrm{Cu}_{\mathrm{i}}^{+}+\mathrm{OH}^{-} \rightarrow \mathrm{Zn}_{\mathrm{i}} / \mathrm{Cu}_{\mathrm{i}}+\cdot \mathrm{OH} \\
& \cdot \mathrm{O}_{2}^{-} / \cdot \mathrm{OH}+\text { organic pollutants } \rightarrow \mathrm{CO}_{2}+\mathrm{H}_{2} \mathrm{O}
\end{aligned}
$$

In fact, photocatalysis is a complicated process, which is associated with not only the structure-related physical properties, but also structure-related catalytic processes. The possible schematic diagram for $\mathrm{Cu}$-doped $\mathrm{ZnO}$ photocatalytic degradation of $\mathrm{RhB}$ dye

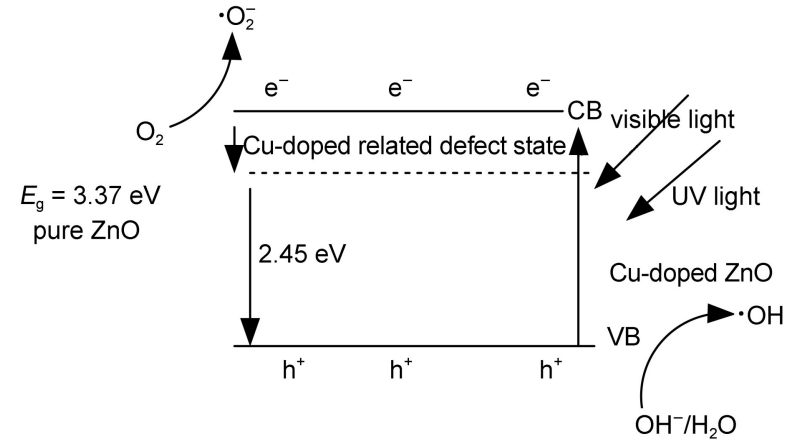

Scheme 1 Proposed photocatalytic mechanism of the porous $\mathrm{Cu}$-doped $\mathrm{ZnO}$ nanorod

and $\mathrm{CH}_{3} \mathrm{CHO}$ gas under visible light irradiation is shown in Scheme 1. The possible scheme can be seen in the follow:

It is generally accepted that, when semiconductor materials are irradiated by UV light or visible light with a photon energy $(h v)$ greater than their band gap energies, an electron $\left(\mathrm{e}^{-}\right)$in the valence band (VB) can be excited to the conduction band (CB) with the simultaneous generation of a hole $\left(\mathrm{h}^{+}\right)$in the $\mathrm{VB}$, so the electrone hole pairs will appear ${ }^{37-39}$.

A suitable scavenger can provide to trap the electron or hole, which is prevented recombination and made subsequent redox reaction. Herein, $\mathrm{Cu}$ ions substitute in $\mathrm{ZnO}$ lattices sever as photogenerated electron trappers to restrain the recombination of electrons and holes. In this process, the electrons at the trapping states can absorbed $\mathrm{O}_{2}$ molecules or dissolved oxygen to produce superoxide radical anions $\left(\cdot \mathrm{O}_{2}^{-}\right)$. In addition, the photo-generated holes can be trapped by the $\mathrm{Cu}$ or Zn-related defect state (such as interstitial site of $\left.\mathrm{Cu}\left(\mathrm{Cu}_{\mathrm{i}}\right)\right)$ and will be further transformed into hydroxyl radicals $(\cdot \mathrm{OH})$. The free radicals $\cdot \mathrm{O}_{2}^{-}$and $\cdot \mathrm{OH}$ produced in the reactions are regarded as strong oxidants to decompose organic pollutants or acetaldehyde $\left(\mathrm{CH}_{3} \mathrm{CHO}\right)$.

\section{Conclusions}

In summary, we reported $\mathrm{Cu}$-doped $\mathrm{ZnO}$ nanorods that were synthesized through a two- step method. The products were characterized by XRD, FESEM, HRTEM, PL, and UV-Vis. The photocatalytic activity was explored by degradation of RhB dye and $\mathrm{CH}_{3} \mathrm{CHO}$ gas. The photocatalytic results show that doping of $\mathrm{Cu}$ into $\mathrm{ZnO}$ can enhance the photocatalytic efficiency of $\mathrm{ZnO}$ under visible light irradiation. Consequently, $\mathrm{Cu}$-doped $\mathrm{ZnO}$ is a promising material for practical application in photocatalytic materials.

\section{References}

(1) Ai, Z. H.; Huang, Y.; Lee, S. C.; Zhang, L. Z. J. Alloy. Compd. 2011, 509, 2044. doi: 10.1016/j.jallcom.2010.10.132

(2) Guo, Q.; Zhou, C. Y.; Ma, Z. B.; Ren, Z. F.; Fan, H. J.; Yang, X. M. Acta Phys. -Chim. Sin. 2016, 32, 28. [郭＼cjkstart庆, 周传耀, 马志 博, 任泽峰, 㚞红军, 杨学明. 物理化学学报, 2016, 32, 28.] doi: 10.3866/PKU.WHXB201512081

(3) Liao, Y. C.; Xie, C. S.; Liu, Y.; Chen, H.; Li, H. Y.; Wu, J. 
Ceram. Int. 2012, 38, 4437. doi: 10.1016/j.ceramint.2012.03.016

(4) Tian, H.; He, J. H.; Liu, L. L.; Wang, D. H.; Hao, Z. P.; Ma, C. Y. Microporous Mesoporous Mat. 2012, 151, 397. doi: 10.1016/j. micromeso.2011.10.003

(5) Yang, L. P.; Liu, Z. Y.; Shi, J. W.; Zhang, Y. Q.; Hu, H.; Shang, W. F. Sep. Purif. Technol. 2007, 54, 204. doi: 10.1016/j. seppur.2006.09.003

(6) You, Y.; Zhang, S. Y.; Wan, L.; Xu, D. F. Appl. Surf. Sci. 2012, 258, 3469. doi: 10.1016/j.apsusc.2011.11.099

(7) Zhang, L.; Fu, H.; Zhang, C.; Zhu, Y. J. Solid State Chem. 2006, 179, 804. doi: 10.1016/j.jssc.2005.12.003

(8) Zhou, J.; Mullins, D. R. Surf. Sci. 2006, 600, 1540. doi: 10.1016/ j.susc.2006.02.009

(9) Zhu, Y.; Yu, F.; Man, Y.; Tian, Q.; He, Y.; Wu, N. J. Solid State Chem. 2005, 178, 224. doi: 10.1016/j.jssc.2004.11.015

(10) Sakatani, Y.; Ando, H.; Okusako, K.; Koike, H.; Nunoshige, J.; Takata, T.; Kondo, J. N.; Hara, M.; Domen, K. J. Mater. Res. 2004, 19, 2100. doi: 10.1557/JMR.2004.0269

(11) Zhao, W.; Ma, W.; Chen, C.; Zhao, J.; Shuai, Z. J. Am. Chem. Soc. 2004, 126, 4782. doi: 10.1021/ja0396753

(12) Sakatani, Y.; Nunoshige, J.; Ando, H.; Okusako, K.; Koike, H.; Takata, T.; Kondo, J. N.; Hara, M.; Domen, K. Chem. Lett. 2003, 32, 1156. doi: 10.1246/cl.2003.1156

(13) Li, X. K.; Ma, D. D.; Zheng, Y. P.; Zhang, H.; Ding, D.; Chen, M. S.; Wan, H. L. Acta Phys. -Chim. Sin. 2015, 31, 1753. [李晓 坤, 马冬冬, 郑燕萍, 张 宏, 丁 丁, 陈明树, 万惠霖. 物理化 学学报, 2015, 31, 1753] doi: 10.3866/PKU.WHXB201507091

(14) Bu, Y. Y.; Chen, Z. Y. RSC Adv. 2014, 4, 45397. doi: 10.1039/ C4RA06641C

(15) Bettinelli, M.; Dallacasa, V.; Falcomer, D.; Fornasiero, P.; Gombac, V.; Montini, T.; Romano, L.; Speghini, A. J. Hazard. Mater. 2007, 146, 529. doi: 10.1016/j.jhazmat.2007.04.053

(16) Yang, X.; Cao, C.; Hohn, K.; Erickson, L.; Maghirang, R.; Hamal, D.; Klabunde, K. J. Catal. 2007, 252, 296. doi: 10.1016/ j.jcat.2007.09.014

(17) Akpan, U. G.; Hameed, B. H. J. Hazard. Mater. 2009, 170, 520. doi: 10.1016/j.jhazmat.2009.05.039

(18) Hayata, K.; Gondalb, M. A.; Khaleda, M. M.; Ahmedc, S.; Shemsi, A. M. Appl. Catal. A: Gen. 2011, 393, 122. doi: 10.1016/j.apcata.2010.11.032

(19) Chen, S. F.; Zhao, W.; Liu, W.; Zhang, S. J. Appl. Surf. Sci. 2008, 255, 2478. doi: 10.1016/j.apsusc.2008.07.115

(20) Rehman, S.; Ullah, R.; Butt, A. M.; Gohar, N. D. J. Hazard.
Mater. 2009, 170, 560. doi: 10.1016/j.jhazmat.2009.05.064

(21) Xu, C.; Cao, L.; Su, G.; Liu, W.; Qu, X.; Yu, Y. J. Alloy. Compd. 2010, 497, 373. doi: 10.1016/j.jallcom.2010.03.076

(22) Dindar, B.; Içli, S. J. Photochem. Photobiol. A: Chem. 2001, 140, 263. doi: 10.1016/S1010-6030(01)00414-2

(23) Yu, J. Y.; Zhuang, S. D.; Xu, X. Y.; Zhu, W. C.; Feng, B.; Hu, J. G. J. Mater. Chem. A 2015, 3, 1199. doi: 10.1039/c4ta04526b

(24) Liang, G. F.; Hu, L. W.; Feng, W. P.; Li, G. D.; Jing, A. H. Appl. Surf. Sci. 2014, 296, 158. doi: 10.1016/j.apsusc.2014.01.065

(25) Xue, H.; Chen, Y.; Xu, X. L.; Zhang, G. H.; Zhang, H.; Ma, S. Y. Phys. E 2009, 41, 788. doi: 10.1016/j.physe.2008.12.017

(26) Kamalianfar, A.; Halim, S. A.; Azak, K. Ceram. Int. 2014, 40, 3193. doi: 10.1016/j.ceramint.2013.09.123

(27) Guo, Q.; Minton, T. K.; Yang, X. M. Chin. J. Catal. 2015, 36, 1649. [郭 庆, Minton, T. K., 杨学明. 催化学报, 2015, 36, 1649.] doi: 10.1016/S1872-206760935-4

(28) Rajneesh, M.; Karthikeyan, K.; Sang-Jae, K. Solid State Commun. 2012, 152, 375. doi: 10.1016/j.ssc.2011.12.008

(29) Sahu, D.; Panda, N. R.; Acharya, B. S.; Panda, A. K. Ceram. Int. 2014, 40, 11041. doi: 10.1016/j.ceramint.2014.03.119

(30) Yang, M. Q.; He, J. H. J. Colloid Interface Sci. 2011, 355, 15. doi: 10.1016/j.jcis.2010.11.022

(31) Li, X. J.; Sheng, J. Y.; Chen, H. H.; Xu, Y. M. Acta Phys. -Chim. Sin. 2015, 31, 540. [李晓金, 盛珈怡, 陈海航, 许宜铭. 物理化 学学报, 2015, 31, 540.] doi: 10.3866/PKU.WHXB201501131

(32) Pawar, R. C.; Choi, D. H.; Lee, J. S.; Lee, C. S. Mater. Chem. Phys. 2015, 151, 167. doi: 10.1016/j.matchemphys.2014.11.051

(33) Yang, M.; He, J. J. Colloid Interface Sci. 2011, 355, 15. doi: 10.1016/j.jcis.2010.11.022

(34) Zhang, Y.; Chen, L.; Zheng, Z.; Yang, F. Solid State Sci. 2009, 11, 1265. Doi:10.1016/j.solidstatesciences.2009.03.018

(35) Segal, S. R.; Suib, S. L.; Foland, L. Chem. Mater. 1997, 9, 2526. doi: $10.1021 / \mathrm{cm} 9702934$

(36) Zhang, W.; Yang, Z.; Wang, X.; Zhang, Y.; Wen, X.; Yang, S. Catal. Commun. 2006, 7, 408. doi.org/10.1016/j. catcom.2005.12.008

(37) Chu, F. H.; Huang, C. W.; Hsin, C. L.; Wang, C. W.; Yu, S. Y. Ye, P. H.; Wu, W. W. Nanoscale 2012, 4, 1471. doi: 10.1039/ clnr10796h

(38) Liu, Y.; Zhao, N.; Gao, W. RSC Adv. 2013, 3, 21666. doi: 10.1039/c3ra42902d

(39) Macwan, D. P.; Dave, P. N.; Chaturvedi, S. J. Mater. Sci. 2011, 46, 3669. doi: 10.1007/s10853-011-5378-y 